\title{
Biological parameters of Cydnodromus picanus and Phytoseiulus persimilis raised on the carmine spider mite, Tetranychus cinnabarinus (Acari: Phytoseiidae, Tetranychidae)
}

\author{
Víctor Tello ${ }^{1}$, Robinson Vargas ${ }^{2}$, Jaime Araya ${ }^{3}$, and Antonieta Cardemil ${ }^{2}$ \\ ${ }^{1}$ Departamento de Agricultura del Desierto, Universidad Arturo Prat. Avenida Arturo Prat 2120, Casilla 121, \\ Iquique, Chile; \\ ${ }^{2}$ Centro Regional de Investigación La Cruz, Instituto de Investigaciones Agropecuarias. Casilla 3, La Cruz, Chile. \\ ${ }^{3}$ Facultad de Ciencias Agronómicas, Universidad de Chile. Santa Rosa 11315, La Pintana, Santiago, Chile.
}

\begin{abstract}
V. Tello, R. Vargas, J. Araya, and A. Cardemil. 2009. Biological parameters of Cydnodromus picanus and Phytoseiulus persimilis raised on the carmine spider mite Tetranychus cinnabarinus (Acari: Phytoseiidae, Tetranychidae). Cien. Inv. Agr. 36(2):277-290. The postembryonic development, consumption and life table parameters of Cydnodromus picanus Ragusa and Phytoseiulus persimilis (Athias-Henriot) were studied at $29.44 \pm 1.47^{\circ} \mathrm{C}$ and 42.35 $\pm 5.01 \%$ of RH with a photoperiod of $14: 10 \mathrm{~h}$ (L:D) in order to evaluate the potential of these predators for feeding on the carmine spider mite Tetranychus cinnabarinus (Boisduval). Eggs, larvae and protonymphs of T. cinnabarinus may be optimal food for C. picanus, which obtained survival rates of $100 \%, 97 \%$ and $93 \%$, respectively, on them. The survival of $P$. persimilis was around $6.7 \%$ with diets based on eggs, larvae and protonymphs, showing a high mortality level by dehydration when fed with eggs. The time of the postembryonic development was significantly shorter $(p<0.05)$ for $C$. picanus than for P. persimilis when they were fed with eggs, larvae and deutonymphs of $T$. cinnabarinus. When fed with eggs and a combination of different stages of $T$. cinnabarinus, the intrinsic rate of growth $\left(r_{m}\right)$ was significantly higher $(\mathrm{p}$ $<0.05$ ) for C. picanus ( 0.289 and 0.307 , respectively) than for P. persimilis $(0.019$ and 0.025 , respectively). The values of the finite rate of growth $(\lambda)$ were also significantly $(p<0.05)$ higher for $C$. picanus (1.34 and 1.36) than for P. persimilis (1.02 and 1.03) when they were nourished with eggs and a mixed diet, respectively. The high values of $r_{m}$ and $\lambda$ found for $C$. picanus in the experimental conditions are indicators of the possible control that this phytoseiid mite, as a predator of $T$. cinnabarinus, would potentially offer under the conditions of lower relative humidity encountered in the arid zone of the desert of Chile.
\end{abstract}

Key words: Biological control, life table, postembryonic development, predation.

\section{Introduction}

Acari predators are important bio-control agents. They are essential in the integrated

Received 02 October 2008. Accepted 20 March 2009. Corresponding author: vtello@unap.cl pest control programs that are becoming of great importance, particularly in the management of phytophagus acari. The family Phytoseiidae is a group of predator acari, with around 2,250 species, that are the subject of intensive studies because of their role as predators of agricultural pests (McMurtry and Croft, 1997). 
In Chile, 48 species of acari phytoseiids have been reported associated with cultivated plants or weeds. Some of these acari have been reported as a factor in regulating populations of phytophagus acari of economic importance, such as Tetranychus urticae Koch, T. cinnabarinus Boisduval, Panonychus ulmi Koch and P. citri McGregor (Ragusa, 2000; Ragusa et al., 2000; Ragusa et al., 2002; Rioja and Vargas, 2008).

A very promising species is Cydnodromus picanus Ragusa [=Neoseiulus picanus (Ragusa), Moraes et al., 2004], a phytoseiid of the sub-family Amblyseiinae, recorded as a new species for science by Ragusa (2000). C. picanus was found on Citrus aurantium in Pica, Iquique ( $20^{\circ} 29^{\prime} 12,4$ " $\mathrm{S}$; $69^{\circ} 19^{\prime} 33,9^{\prime}$ ' W), Region of Tarapacá. According to Ragusa et al. (2000), this species could be used in hot and dry agroecosystems, where it is hard to find acari phytoseiids that are adapted to these extreme conditions to control tetraniquids. On the basis of the classification of McMurtry and Croft (1997), C. picanus is a general predator belonging to the type III life style. This was confirmed by the works by Ragusa et al. (2000) and Rioja and Vargas (2008), who proved that this species can grow and develop on pollen of Hirschfeldia incana, Persea americana, Oxalis $\mathrm{sp}$, and Ricinus sp.

In relation to its predatory capacity, Ragusa et al. (2000) determined that the life parameters of C. picanus turn it into a promising candidate to be used in programs of biological control of the two-spotted mite (T. urticae) and the citrus red mite [(Panonychus citri (McGregor)]. In addition, Rioja and Vargas (2008), reached a similar conclusion after evaluating the predatory capacity of $C$. picanus on avocado red mite [Oligonychus yothersi (McGregor)] since it has a high intrinsic rate of growth $\left(r_{m}\right)$ as compared with $O$. yethersi, indicating that its predator population has the capacity to control this phytophagus acarus through generations. Therefore, these authors state that $C$. picanus is a promising natural enemy of avocado red mite, and its potential use has to be evaluated in the integrated management of citrus and avocado acari.
The predator acarus Phytoseiulus persimilis (Athias-Henriot) is specialized in consuming phytophagus acari (Tetranychus spp.). It has been used in the biological control of T. urticae in strawberry through massive releases in areas such as North America (Strand, 1994), Northern Europe (Scopes, 1985), the Mediterranean Sea (Benuzzi and Antoniacci, 1995) and Korea (Kim and Park, 2006). According to Naher and Haque (2007), $P$. persimilis is the most commercialized and widely released phytoseiid predator in greenhouses. It has been widely studied for its capacity for the biological control of tetraniquid acari in many crops (Sabelis, 1985; Naher and Haque, 2007). Çakmak et al. (2005) have suggested that $P$. persmilis has enormous potential for the biological control of T. cinnabarinus in protected strawberry in Aydin (Turkey), where temperatures over $30{ }^{\circ} \mathrm{C}$ and relative humidities (RHs) below $60 \%$ are unfavorable conditions for the development of predatory acari. Its predatory action on phytophagus mites in Chile is practically unknown.

The carmine spider mite is associated with more than 120 host plants of economic importance worldwide, including cotton, strawberry, ornamental plants, deciduous fruit trees, tomato, eggplant, and other vegetables, with a wide distribution in different parts of the world (Çakmak and Demiral, 2007).

In Chile, the prevailing climatic conditions in the desert zone (high temperature and low RH) are very favorable for the development of phytophagus acari. An important species within this group is the carmine spider mite, T. cinnabarinus. The primary hosts of this mite are alfalfa, carnation, bean, strawberry and melon in Chile. It is distributed from the I Region to the VII Region. In the I Region (Tarapacá), it is mainly associated with melon and carnation, and it is usually controlled chemically (Klein and Waterhouse, 2001).

The purpose of this study was to evaluate the biological parameters of $C$. picanus and $P$. persimilis on a diet composed of carmine spider mite at different stages of development in similar experimental conditions to those found in the dry zone of the desert of Chile. 


\section{Materials and methods}

The bioassays were conducted at the Centro Regional de Investigación La Cruz, (Instituto de Investigaciones Agropecuarias (INIA), La Cruz, Chile) at $29.44 \pm 1.47^{\circ} \mathrm{C}$ and $42.35 \pm 5.01 \%$ relative humidity $(\mathrm{RH})$ with a photoperiod of 14:10 h (light:darkness). The phytoseiid acari predators $C$. picanus and $P$. persimilis were used. C. picanus was collected from trees of $C$. aurantium in Pica, Chile, and P. persimili was collected from Chilean bell flower (Nolana sp., Nolanaceae) in La Cruz, Chile (32 $49^{\prime}$ S; $71^{\circ} 17^{\prime}$ $\mathrm{W})$. These phytoseiid predators were reared to increase their population size, and they were fed with two-spotted spider mites (T. urticae). The carmine spider mite (T. cinnabarinus) was collected from Quillota (Region of Valparaíso) and bred in carnations (Dianthus caryophyllus 'Celta').

The bioassays with phytoseiid predators were performed in $6 \times 6 \mathrm{~cm}$ black acrylic dishes (Swirski et al., 1970). Glue (Point Sticken Glue, Point Chile S.A.) was placed in the margin of the dishes to prevent acari from escaping from dishes. The observations were made with the aid of a stereoscopic microscope at 40X magnification (Zeiss Stemi, Germany) during all the periods of work.

\section{Postembryonic development}

The potential development of $C$. picanus and $P$. persimilis from the state of egg to adult was determined in the bioassay of postembryonic development. C. picanus and $P$. persimilis were fed simple diets consisting of a single prey state that consisted of eggs, larvae, protonymphs, deutonymphs, or adults of $T$. cinnabarinus. One 20-h-old egg (as a maximum) was placed on a $6 \times 6 \mathrm{~cm}$ diameter dish and observed daily at the same time until the adult state was obtained. These eggs were obtained from different females that were reared for approximately four generations from the beginning of rearing. Food was administered daily and consisted of diets of 10 individuals of each prey state. In addition, tests in high $\mathrm{RH}$ were carried out with $P$. persimilis, in $57 \times 42 \times 19 \mathrm{~cm}$ plastic chambers at $28.12 \pm 0.05^{\circ} \mathrm{C}$ and $76.50 \pm 0.24 \% \mathrm{RH}$. The diets evaluated in these conditions were eggs, protonymphs and deutonymphs of $T$. cinnabarinus. The survival, duration and consumption of each state of development of the phytoseiid predators were evaluated. Each bioassay was replicated 30 times, each replicate consisting of one phytoseiid egg per dish.

\section{Prey consumption}

The consumption of prey was evaluated in all the pre-imaginal stages and in virgin and mated females (ovipositors) using eggs of $T$. cinnabarinus. In the tests with juvenile stages, it was carried out as explained above for the postembryonic development tests, administering 30 eggs of $T$. cinnabarinus for each individual per day. In the tests with virgin females, recently emerged females were taken from isolated dishes. Each female was isolated in a dish, and the diet consisted on 30 eggs per day of T. cinnabarinus. In the tests with mated females, a young female and a young male were placed in an isolated dish, and after first oviposition was recorded, the female was transferred to a new dish with 40 eggs per day of $T$. cinnabarinus. The numbers of eggs consumed during all the developmental preimaginal stages were counted, or until the female died. Each test was replicated 25 times, and each replicate consisted of one juvenile per female phytoseiid per dish.

\section{Life table parameters}

The effects of two diets on the life table parameters of $C$. picanus and $P$. persimilis were determined. The first diet consisted of 40 eggs per day of the prey, and the second was a mixed diet based on a mixture of different stages (30 eggs +15 immature mobile +5 adult females of $T$. cinnabarinus). The methodology described previously was used (Birch, 1948; Ragusa et al., 2000; Vargas et al., 2005). The parameters evaluated were the intrinsic rate of growth $\left(r_{m}\right)$, the net 
rate of reproduction $\left(R_{0}\right)$, generational time $(T)$ and the finite rate of natural growth $(\lambda)$. A pair of phytoseiids was placed in each dish; the oviposture was recorded every $24 \mathrm{~h}$ until the female died. The dead males were replaced to fertilize the female constantly. Each test had 25 replicates of a single phytoseiid female per dish.

The parameters of the phytoseiid predators and the parameters of $T$ cinnabarinus were compared. For this purpose, the parameters of $T$ cinnabarinus were obtained by a method previously proposed with some modifications (Kazak and Kibriti, 2008). Rectangular pieces $\left(3.6 \mathrm{~cm}^{2}\right)$ of carnation leaves were obtained only from completely developed leaves of similar ages. The leaf pieces were placed in plastic Petri dishes of $12 \mathrm{~cm}$ diameter on a cotton layer water saturated with the abaxial surface upwards. A female and a male were placed in each dish on each piece of leaf. The Petri dishes were placed in plastic trays $(41 \times 31 \times 7 \mathrm{~cm})$ over a saturated sponge. Males were replaced if they died, and oviposture was recorded every $24 \mathrm{~h}$.

\section{Design and statistical analysis}

A completely randomized design was used for all the experiments. The data for postembryonic development, the duration of adult phases and consumption were transformed to $\log (\mathrm{x}+1)$ before analysis (Zar, 2006). The percent survival was normalized through the angular transformation $\operatorname{arcosin} \sqrt{ } \mathrm{x} \cdot \%^{-1}$ (Zar, 2006). An analysis of variance (ANOVA) was subsequently performed, and means were separated according to Tukey's multiple comparison test.

The consumption rates of the two phytoseiid species were compared using the Student's ttest. The life table parameters of $C$. picanus, $P$. persimilis, and $T$. cinnabarinus were calculated with the aid of a computer program written in BASIC (Abou-Setta et al., 1986). For comparisons between the life table parameters of the two phytoseiids species, the standard deviation was estimated at a confidence interval of $95 \%$ using Jacknife's statistical technique (Maia et al., 2000) available in SAS (SAS Institute, Cary, NC, USA) (La Rossa and Kahn, 2003; Ansaloni et al., 2007). Subsequently, the biological parameters were compared using the Tukey's multiple comparison tests.

\section{Results}

Survival and duration of the life cycle of $C$. picanus and P. persimilis

Diets had a highly significant effect $(\mathrm{F}=359.46$; d.f. $=5,170 ; \mathrm{p}<0.0001)$ on the development of C. picanus at $42 \% \mathrm{RH}$ (Table 1). The simple diets based on eggs, larvae and protonymphs of the carmine spider mite positively affected survival, resulting in over $93.33 \%$ survival. The deutonymph stage and adults negatively affected survival and were statistically similar to water controls. Imagoes of $C$. picanus were not obtained when the simple diet consisted only of adults of T. cinnabarinus.

In the case of $P$. persimilis bred at $42 \% \mathrm{RH}$, an extremely low survival $(<9.44 \%)$ was obtained regardless of the composition of the diet (Table 1). The means among diets were not significantly different from the water control $(\mathrm{F}=0.50$; d.f. $=5,174 ; p=0.77)$. The highest mortality appeared in the egg stage, reaching values over $90 \%$. All of the few survivors reached the adult stage of their development, including the ones on the diet based exclusively on adults of $T$. cinnabarinus that produced phytoseiid imagoes. Due to the very low eclosion obtained in the tests made under $42 \%$ of $\mathrm{RH}$, and to discard the effect of any other factor except those that were not the experimental conditions such as manipulation, cannibalism or other, tests in a humid chamber were made at $28.12 \pm 0.05^{\circ} \mathrm{C}$ and $76.50 \pm 0.24 \%$ RH. Three states of the prey were evaluated: eggs, protonymphs and deutonymphs. Under these conditions, results of $100 \%$ eclosion success and over $95.83 \%$ survival to the adult stage were obtained, the differences among the diets were not significant, but statistically different to the water control (Table 1) $(\mathrm{F}=561.00$; d.f. $=3$, $92 ; \mathrm{p}<0.0001)$. 
Table 1. Effect of diets consisting of different stages of development of the carmine spider mite (Tetranychus cinnabarinus) on the postembryonic development of Cydnodromus picanus and Phytoseiulus persimilis.

\begin{tabular}{|c|c|c|c|c|c|c|c|c|}
\hline \multirow[b]{3}{*}{ Diet } & \multicolumn{6}{|c|}{ Individuals reaching adulthood, no. } & \multirow[b]{3}{*}{ Survival $^{1}, \%$} & \multirow{3}{*}{$\begin{array}{l}\text { Duration } \\
\text { Egg-adult }^{1} \\
\text { days } \pm \mathrm{SE}\end{array}$} \\
\hline & \multirow[b]{2}{*}{$\mathrm{n}$} & \multirow[b]{2}{*}{ Eggs } & \multirow[b]{2}{*}{ Protonymph } & \multirow[b]{2}{*}{ Deutonymph } & \multicolumn{2}{|c|}{ Adult } & & \\
\hline & & & & & Female & Male & & \\
\hline \multicolumn{9}{|c|}{ C. picanus ( $42 \%$ relative humidity) } \\
\hline Egg & 28 & 28 & 28 & 28 & 22 & 6 & $100.00 \pm 0.00 \mathrm{a}$ & $4.05 \pm 0.05 \mathrm{a}$ \\
\hline Larvae & 28 & 28 & 28 & 28 & 21 & 7 & $96.55 \pm 3.46 \mathrm{a}$ & $4.33 \pm 0.13 \mathrm{a}$ \\
\hline Protonymph & 30 & 28 & 28 & 28 & 20 & 8 & $93.33 \pm 4.63 \mathrm{a}$ & $5.45 \pm 0.14 b$ \\
\hline Deutonymph & 21 & 14 & 14 & 5 & 1 & 0 & $3.45 \pm 3.45 b$ & $4.00 \pm 0.00 \mathrm{a}$ \\
\hline Adult & 22 & 22 & 22 & 9 & 0 & 0 & $0.00 \pm 0.00 \mathrm{~b}$ & - \\
\hline Water & 30 & 30 & 30 & 0 & 0 & 0 & $0.00 \pm 0.00 \mathrm{~b}$ & - \\
\hline \multicolumn{9}{|c|}{ P. persmilis ( $42 \%$ relative humidity) } \\
\hline Egg & 30 & 2 & 2 & 2 & 1 & 1 & $6.67 \pm 4.63 \mathrm{a}$ & $5.00 \pm 0,00 \mathrm{a}$ \\
\hline Larvae & 30 & 2 & 2 & 2 & 2 & 0 & $6.67 \pm 4.63 \mathrm{a}$ & $5.00 \pm 0,00 \mathrm{a}$ \\
\hline Protonymph & 30 & 2 & 2 & 2 & 1 & 1 & $6.67 \pm 4.63 \mathrm{a}$ & $5.00 \pm 0,00 \mathrm{a}$ \\
\hline Deutonymph & 30 & 3 & 3 & 3 & 2 & 1 & $9.44 \pm 5.28 \mathrm{a}$ & $6.00 \pm 0,00 \mathrm{~b}$ \\
\hline Adult & 30 & 2 & 2 & 2 & 1 & 1 & $6.67 \pm 4.63 \mathrm{a}$ & $6.00 \pm 0.00 \mathrm{~b}$ \\
\hline Water & 30 & 2 & 2 & 0 & 0 & 0 & $0.00 \pm 0.00 \mathrm{a}$ & - \\
\hline \multicolumn{9}{|c|}{ P. persmilis ( $77 \%$ relative humidity) } \\
\hline Egg & 24 & 24 & 24 & 24 & 14 & 10 & $100.00 \pm 0.00 \mathrm{a}$ & $4.57 \pm 0.14 \mathrm{a}$ \\
\hline Protonymph & 24 & 24 & 24 & 24 & 15 & 8 & $95.83 \pm 4.17 \mathrm{a}$ & $5.20 \pm 0.14 \mathrm{~b}$ \\
\hline Deutonymph & 24 & 24 & 24 & 24 & 12 & 12 & $100.00 \pm 0.00 \mathrm{a}$ & $5.67 \pm 0.14 b$ \\
\hline Water & 24 & 24 & 24 & 0 & 0 & 0 & $0.00 \pm 0.00 \mathrm{~b}$ & - \\
\hline
\end{tabular}

${ }^{1}$ Means followed by different letters within each column are significantly different according to the Tukey's test $(p<0.05)$. Data are reported as the mean \pm standard error.

\section{Consumption}

Highly significant differences were obtained for the rates of consumption among the different stages of $C$. picanus $(\mathrm{F}=516.54$; d.f. $=4$, $131 ; \mathrm{p}<0.0001)$ and $P$. persimilis $(\mathrm{F}=335.74$; d.f. $=4,51 ; \mathrm{p}<0.0001$ ) (Figure 1). Independent of the phytoseiid species, larvae did not feed on eggs, while the protonymphs of $C$. picanus and $P$. persimilis $(\mathrm{t}=0.02$, d.f. $=28, \mathrm{p}=0.988)$ had approximately the same rate of egg consumption, on average, $3.2 \pm 0.33$ and $3.0 \pm 1.00$ egg. day ${ }^{-1}$, respectively. Deutonymphs of both phytoseiids were not significant differences in their consumption of $T$. cinnabarinus eggs $(\mathrm{t}=0.53$, d.f. $=28, \mathrm{p}=0.604)$ with averages of $6.4 \pm 0.33$ and $7.0 \pm 1.00$ egg. day ${ }^{-1}$ for $C$. picanus and $P$. persimilis, respectively. In the case of the adult females, there were highly significant differences in the rate of consumption between $C$. picanus and $P$. persimilis when considering virgin females $(\mathrm{t}=24.99$; d.f. $=24 ; \mathrm{p}<0.001)$ as well as mated females $(\mathrm{t}=4.05$, d.f. $=48, \mathrm{p}<0.001)$. In both cases, the females of $P$. persimilis consumed, on average, a higher number of eggs than the females of $C$. picanus (Figure 1). 


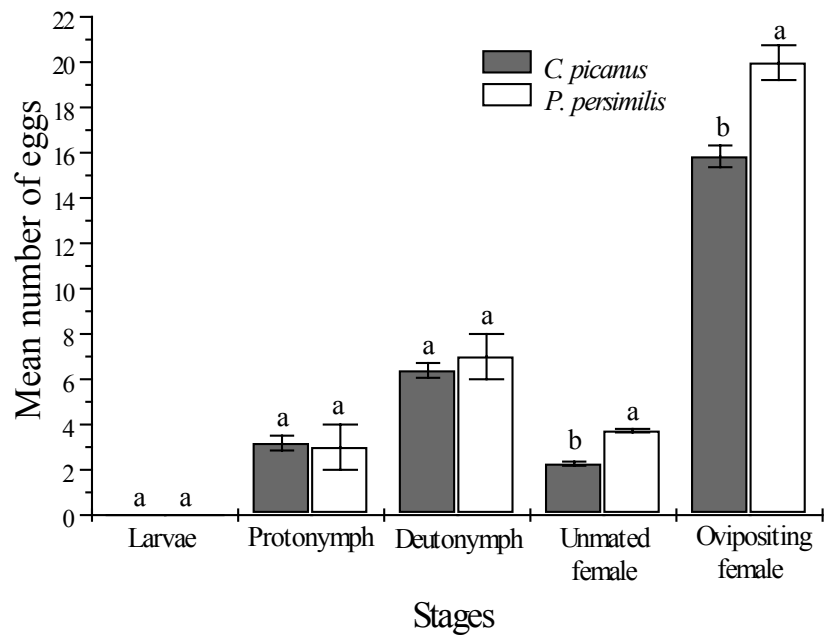

Figure 1. Daily consumption of eggs of Tetranychus cinnabarinus by different stages of Cydnodromus picanus and Phytoseiulus persimilis. Bars followed by different letters within each stage denote significant differences according to the Student's t test $(p<0.05)$. Bars $=$ standard errors.

\section{Parameters of their life table}

Rates of oviposition and the duration of adult stages. The period of preoviposition was very short in C. picanus fed with eggs of T. cinnabarinus, but it was considerably longer in $P$. persimilis $(\mathrm{F}=68.02$; d.f. $=3,96 ; \mathrm{p}<0.0001)(\mathrm{Ta}-$ ble 3). Independent of the diet, the oviposition, postoviposition and longevity were significantly longer in C. picanus than $P$. persimilis fed with eggs of $T$. cinnabarinus $(\mathrm{F}=26.40$; d.f. $=3,96$; $\mathrm{p}<0.0001, \mathrm{~F}=44.13$; d.f. $=3,96 ; \mathrm{p}<0.0001$ and $\mathrm{F}=33.59$; d.f. $=3,96 ; \mathrm{p}<0.0001$, respectively). The number of eggs per female was significantly higher in $C$. picanus than $P$. persimilis $(\mathrm{F}=12.75$; d.f. $=3,96 ; \mathrm{p}<0.0001)$. Differences between the two diets were not significant.

Rate of net reproduction $\left(R_{0}\right)$. The values of $R_{0}$ of the three species were significantly different $(\mathrm{F}=2,625.81 ;$ d.f. $=4,74 ; \mathrm{p}<0.0001)$ (Table 4). The highest $R_{0}$ value was obtained for $T$. cinnabarinus. Independent of the diet, $C$. picanus exhibited higher $R_{0}$ values than $P$. persimilis, which had extremely low $R_{0}$ values while feeding on eggs and the mixed diet of T. cinnabarinus, reflecting the limited viability of the eggs of $P$. persimilis at this low reproductive capacity under experimental conditions, especially under the low RH.

Intrinsic rate of growth $r_{m}$. The $r_{m}$ values obtained for $P$. persimilis were lower than the $r_{m}$ values obtained for $C$. picanus and were lower than the $r_{m}$ values of $T$. cinnabarinus $(\mathrm{F}=9,196.20$; d.f. $=4,75 ; \mathrm{p}<0.0001$; Table 4). The highest $r_{m}$ values were obtained for $C$. picanus fed with a mixed diet or with eggs of $T$. cinnabarinus. Both values were, in addition, significantly higher than the $r_{m}$ values of $T$. cinnabarinus. The $r_{m}$ values obtained for $C$. picanus on the two diets were the highest, exceeding those of $P$. persimilis, and even more interestingly, they were greater than the $r_{m}$ of $T$. cinnabarinus, indicating that the populations of $C$. picanus have the capacity to control T. cinnabarinus for generations.

Generational time. The generational time was different among the three acarus species used in this study $(\mathrm{F}=1,645.59$; d.f. $=4,75 ; \mathrm{p}<0.0001)$ (Table 4). T. cinnabarinus had the longest and P. persimilis the shortest generational times with diets of all the growth stages and eggs of 
Table 2. Effect of relative humidity (RH) on the proportion of eggs that survive for different phytoseiid species, results obtained in this study are compared with references.

\begin{tabular}{|c|c|c|c|c|c|}
\hline \multirow[b]{2}{*}{ Phytoseiidae } & \multirow[b]{2}{*}{ Food } & \multicolumn{3}{|c|}{ Survival (\%) at \%RH: } & \multirow[b]{2}{*}{ References } \\
\hline & & 40 & 50 & 60 & \\
\hline Cydnodromus picanus & Tetranychus cinnabarinus & 100.0 & - & - & Present study \\
\hline Phytoseiulus persimilis & Tetranychus cinnabarinus & 6.7 & - & - & Present study \\
\hline Euseius citrifolius & Pollen of Typha angustifolia & 57.0 & 90.0 & 97.0 & Vis et al., 2006 \\
\hline Metaseiulus camelliae & Tenuipalpus heveae & 13.0 & 37.0 & 87.0 & Vis et al., 2006 \\
\hline Iphiseiodes zuluagai & Pollen of Typha angustifolia & 3.0 & 17.0 & 33.0 & Vis et al., 2006 \\
\hline Zetzellia malvinae & Tenuipalpus heveae & 0.0 & 10.0 & 50.0 & Vis et al., 2006 \\
\hline Amblyseius acalyphus & $\begin{array}{l}\text { Pollen of Thypa angustifolia } \\
\text { + Tenuipalpus heveae }\end{array}$ & 0.0 & 10.0 & 40.0 & Vis et al., 2006 \\
\hline Agistemus floridanus & Tenuipalpus heveae & 0.0 & 7.0 & 33.0 & Vis et al., 2006 \\
\hline Iphiseius degenerans & Pollen of Ricinus communis & - & 21.8 & 68.1 & Courcy et al., 2004 \\
\hline Phytoseiulus persimilis & Tetranychus urticae & - & 2.6 & 24.9 & Courcy et al., 2004 \\
\hline Neoseiulus cucumeris & Tyrophagus sp & - & 0.0 & 21.6 & Courcy et al., 2004 \\
\hline Neoseiulus caifornicus & Tetranychus urticae & 一 & 0.0 & 4.9 & Courcy et al., 2004 \\
\hline
\end{tabular}

Table 3. Durations of the period of the adult stage and the oviposition rates of Cydnodromus picanus and Phytoseiulus persimilis fed on two types of diets based on stages of development of Tetranychus cinnabarinus.

\begin{tabular}{|c|c|c|c|c|}
\hline \multirow[b]{2}{*}{ Periods } & \multicolumn{2}{|c|}{ Simple diet ${ }^{1}$} & \multicolumn{2}{|c|}{ Mixed diet ${ }^{2}$} \\
\hline & $\begin{array}{l}\text { C. picanus } \\
(\mathrm{n}=25)\end{array}$ & $\begin{array}{l}\text { P. persimilis } \\
(\mathrm{n}=25)\end{array}$ & $\begin{array}{l}\text { C. picanus } \\
(\mathrm{n}=25)\end{array}$ & $\begin{array}{l}\text { P. persimilis } \\
(\mathrm{n}=25)\end{array}$ \\
\hline \multicolumn{5}{|c|}{ Duration of the adult stages, days } \\
\hline Preoviposition & $0.68 \pm 0.10 c^{3}$ & $2.72 \pm 0.21 \mathrm{a}^{3}$ & $1.00 \pm 0.08 \mathrm{~b}^{3}$ & $2.60 \pm 0.12 \mathrm{a}^{3}$ \\
\hline Oviposition & $18.00 \pm 0.33 \mathrm{a}$ & $9.08 \pm 0.71 b$ & $14.40 \pm 0.93 \mathrm{a}$ & $8.52 \pm 0.95 b$ \\
\hline Postoviposition & $11.60 \pm 0.71 \mathrm{a}$ & $6.68 \pm 0.32 \mathrm{~b}$ & $5.60 \pm 0.82 \mathrm{~b}$ & $1.84 \pm 0.56 \mathrm{c}$ \\
\hline Longevity & $30.36 \pm 0.83 \mathrm{a}$ & $18.48 \pm 0.81 \mathrm{~b}$ & $21.00 \pm 1.57 \mathrm{~b}$ & $12.96 \pm 1.46 \mathrm{c}$ \\
\hline \multicolumn{5}{|c|}{ Oviposition, eggs, no. } \\
\hline Total egg $\cdot$ female $^{-1}$ & $48.96 \pm 1.98 \mathrm{a}$ & $26.56 \pm 2.40 \mathrm{~b}$ & $36.68 \pm 2.59 \mathrm{a}$ & $28.20 \pm 3.01 \mathrm{~b}$ \\
\hline Egg $\cdot$ female $^{-1} \cdot$ day $^{-1}$ & $2.72 \pm 0.11 \mathrm{~b}$ & $2.90 \pm 0.12 b$ & $2.58 \pm 0.11 \mathrm{~b}$ & $3.35 \pm 0.08 \mathrm{a}$ \\
\hline
\end{tabular}

${ }^{1}$ Daily diet consisted of 40 eggs of $T$. cinnabarinus.

${ }^{2}$ Daily diet consisted of a mix of 30 eggs plus 15 immature mobiles plus 5 adult females of $T$. cinnabarinus.

${ }^{3}$ Means followed by different letters within each row are significantly different according to Tukey's test $(\mathrm{p}=0.05)$. Data are reported as the mean \pm standard error.

T. cinnabarinus. For the two predators, in the different diets, the generational time was rather similar, where $C$. picanus fed with a mixed diet had the shortest generational time. Considering $\mathrm{R}_{0}$ and $\mathrm{r}_{\mathrm{m}}$, it is possible to estimate that $C$. picanus fed with a mixed diet of life stages of $T$. cinnabarinus will multiply 21.8 times in approximately 10 days.
Finite rate of growth. The finite rate of growth also differed significantly between species $(\mathrm{F}=10,318.64 ;$ d.f. $=4,75 ; \mathrm{p}<0.0001)$. C. picanus fed with either of the two diets had the highest values, but these differed from each other in that the mixed diet was the best. T. cinnabarinus obtained a higher $\lambda$ than $P$. persimilis, with values statistically equal between the two diets (Table 4). 
Table 4. Life table parameters of Cydnodromus picanus, Phytoseiulus persimilis, and the carmine spider mite (Tetranychus cinnabarinus) $(\mathrm{n}=25)$.

\begin{tabular}{crrrrrr}
\hline \multirow{2}{*}{$\begin{array}{c}\text { Biological } \\
\text { parameters }\end{array}$} & \multicolumn{2}{c}{ Simple diet $^{2}$} & & \multicolumn{3}{c}{ Mixed diet $^{3}$} \\
\cline { 2 - 3 } \cline { 5 - 6 } \cline { 5 - 6 } & \multicolumn{1}{c}{ C. picanus } & \multicolumn{1}{c}{ P. persimilis } & \multicolumn{1}{c}{ C. picanus } & P. persimilis & T. cinnabarinus \\
\hline$R_{0}$ & $29.129 \pm 1.177 \mathrm{~b}^{4}$ & $1.226 \pm 0.111 \mathrm{~d}^{4}$ & & $21.823 \pm 1.541 \mathrm{c}^{4}$ & $1.302 \pm 0.139 \mathrm{~d}^{4}$ & $40.962 \pm 4.317 \mathrm{a}^{4}$ \\
$r_{m}$ & $0.289 \pm 0.003 \mathrm{~b}$ & $0.019 \pm 0.008 \mathrm{e}$ & & $0.307 \pm 0.004 \mathrm{a}$ & $0.025 \pm 0.009 \mathrm{~d}$ & $0.200 \pm 0.005 \mathrm{c}$ \\
$T$ & $11.677 \pm 0.148 \mathrm{~b}$ & $11.112 \pm 0.315 \mathrm{c}$ & & $10.067 \pm 0.310 \mathrm{~d}$ & $10.924 \pm 0.476 \mathrm{c}$ & $18.552 \pm 0.471 \mathrm{a}$ \\
$\lambda$ & $1.335 \pm 0.004 \mathrm{~b}$ & $1.019 \pm 0.008 \mathrm{~d}$ & & $1.359 \pm 0.006 \mathrm{a}$ & $1.025 \pm 0.009 \mathrm{~d}$ & $1.222 \pm 0.006 \mathrm{c}$ \\
\hline
\end{tabular}

${ }^{1}$ Biological parameters $\mathrm{R}_{0}=$ net reproductive rate, $\mathrm{r}_{\mathrm{m}}=$ intrinsic rate of growth, $\mathrm{T}=$ mean generation time, and $\lambda=$ finite rate of growth.

${ }^{2}$ Daily simple diet consisted of 40 eggs of $T$. cinnabarinus.

${ }^{3}$ Daily mixed diet consisted of 30 eggs plus 15 immature mobiles plus 5 adult females of $T$. cinnabarinus.

${ }^{4}$ Means followed by different letters within each row are significantly different according to Tukey's test $(\mathrm{p}=0.05)$.

\section{Discussion}

The percentage of the viability of $C$. picanus eggs obtained in this study greatly exceeds what was previously reported in the literature regarding the survival of eggs at low RH. In this study, $100 \%$ eclosion success was obtained at $42 \% \mathrm{HR}$.

De Vis et al. (2006) stated that Euseius citrifolius (Acari: Phytoseiidae) is a highly promising species for use as a biocontrol agent in arid environments. Our results with C. picanus allow us to point out that its performance in conditions of low RH could potentially surpass the performance of E. citrifolius, as C. picanus is a native species of desert environments that evolved in conditions of extreme aridity.

In regards to the lack of specific predatory species from arid environments (Walzer et al., 2007), it has to be added that the phytoseiid species available commercially do not work in these types of conditions (Zundell et al., 2007). According to Bakker et al. (1993), air humidity is one of the main factors influencing the efficiency of the acarus predators. Sabelis (1985) and Walzer et al. (2007) confirm this point, showing that the egg is the most susceptible state to the most adverse climatic conditions. The other life stages are mobile and may search for more favorable microhabitats to protect themselves from adverse conditions. The prevalence of $C$. picanus in the desert zone of Chile may be partially explained by its capacity to tolerate conditions of low RH. In these regions, RH may reach very low levels annually (10-30\%).
Both phytoseiid species showed a high consumption of eggs. Oku et al. (2004), when trying to explain the higher preference for this food, hypothesized that they would be more accessible than adults, which take refuge in the web in the presence of predators. Furuichi et al. (2005) did not find any differences when offering a mix of T. kanzawai females in the state of teliochrysalids (the quiescent state immediately previous to adult emergence) and adult females to Neosiulus womersleyi. Both diets were not favorable compared to the results obtained with eggs of the red mite. Adult stages seem to provide less nutritional benefits, or their predation represents a higher energy cost, as they have certain characteristics such as wax layers in their integumentary system or a harder cuticle.

The larvae of both phytoseiids did not feed on any of the states of $T$. cinnabarinus offered as prey. This is the case of many phytoseiids with a type I life style, especially species of Phytoseiulus (McMurtry and Croft, 1997; Ferrero et al., 2007). In the case of C. picanus, the results obtained coincide completely with previous reports (Ragusa et al., 2000). In the case of $P$. persimilis, similar results were reported previously when larvae of $P$. persimilis were fed with eggs of $T$. cinnabarinus or immature states of $T$. urticae (Ashihara et al., 1978; Chittenden and Saito, 2001).

For C. picanus, the duration of the adult phase is similar to the duration obtained when feeding the predator with eggs of $T$. urticae, coinciding especially in the longevity of approximately 30 days (Ragusa et al., 2000). In this regard, Ragusa et al. (2000) indicated that the most indica- 
tive value to compare the reproductive capacity of different phytoseiid acari is the total number of eggs laid by a female, as the number of eggs.female ${ }^{-1} \cdot$ day $^{-1}$ is regulated by the duration of the oviposition period.

The net reproductive rates obtained for $C . p i-$ canus when fed with eggs and a mixed diet based on T. cinnabarinus stages were similar to the results reported by Ragusa et al. (2000). Values of $R_{0}$ for different phytoseiid species are shown in Table 4 . The extremely low values for $P$. persimilis compared to those reported in the literature confirm its diminished reproductive potential (Table 5).
Ragusa et al. (2000) obtained a high value of $r_{m}$ for $C$. picanus fed with eggs of T. urticae (0.377), but a low value for P. citri (0.209) fed the same. These values and the values obtained in this study (including the two diets) are rather similar to the values for other type I specialized predators (McMurtry and Croft, 1997), such as Phytoseiulus (Table 5). On the other hand, Rioja and Vargas (2008) indicated that the $r_{m}$ values of C. picanus fed with two different diets (immature states and a mixture of all the states) of Oligonychus yothersi (McGregor) were 0.25 and 0.24 , respectively, rather close to the $r_{m}$ values presented by type III generalist predators, such as Amblyseius andersoni (Table 5) (Ragusa et al., 2000).

Table 5. Demographic parameters for species of phytoseiids fed on eggs of different species of mites of the genus Tetranychus, at the different temperature $\left({ }^{\circ} \mathrm{C}\right)$ and relative humidity $(\% \mathrm{RH})$ conditions indicated for each species.

\begin{tabular}{|c|c|c|c|c|c|c|c|}
\hline \multirow[b]{2}{*}{ Phytoseiidae } & \multirow[b]{2}{*}{ Prey } & \multicolumn{4}{|c|}{ Biological parameters $^{1}$} & \multirow{2}{*}{$\begin{array}{c}\text { Experimental } \\
\text { conditions } \\
{ }^{\circ} \mathrm{C} ; \% \mathrm{RH}\end{array}$} & \multirow[b]{2}{*}{ Reference } \\
\hline & & $\mathrm{r}_{\mathrm{m}}$ & $\lambda$ & $\mathrm{T}$ & $\mathrm{R}_{\mathrm{o}}$ & & \\
\hline C. picanus & T. cinnabarinus & 0.289 & 1.335 & 11.68 & 29.13 & $29 ; 42 \pm 5$ & This study \\
\hline P. persimilis & T. cinnabarinus & 0.019 & 1.019 & 11.11 & 1.23 & $29 ; 42 \pm 5$ & This study \\
\hline P. persimilis & T. ludeni & 0.424 & - & 11.57 & 40.78 & $25 ; 70-80$ & Escudero and Ferragut, 2005 \\
\hline P. longipes & T. evansi & 0.416 & 1.380 & 8.17 & 13.84 & $30 ; 80 \pm 1$ & Ferrero et al., 2007 \\
\hline C. picanus & T. urticae & 0.377 & 1.458 & 9 & 29.9 & $26 ; 70 \pm 5$ & Ragusa et al., 2000 \\
\hline P. persimilis & T. urticae & 0.373 & - & 12.85 & 45.61 & $25 ; 70-80$ & Escudero and Ferragut, 2005 \\
\hline P. persmilis & T. turkestani & 0.367 & - & 12.79 & 43.02 & $25 ; 70-80$ & Escudero and Ferragut, 2005 \\
\hline C. californicus & T. ludeni & 0.337 & - & 16.04 & 47.37 & $25 ; 70-80$ & Escudero and Ferragut, 2005 \\
\hline C. californicus & T. urticae & 0.311 & 1.365 & 11.23 & 32.95 & $25 ; 70-80$ & Gotoh et al., 2006 \\
\hline C. californicus & T. kanzawai & 0.306 & 1.359 & 11.5 & 33.94 & $25 ; 70-80$ & Gotoh et al., 2006 \\
\hline P. longipes & T. evansi & 0.293 & 1.23 & 12.92 & 13.88 & $25 ; 80 \pm 1$ & Ferrero et al., 2007 \\
\hline C. californicus & T. urticae & 0.285 & 1.250 & 16.79 & 16.74 & $30 ; 70-80$ & Canlas et al., 2006 \\
\hline C. californicus & T. urticae & 0.283 & - & 17.46 & 49.25 & $25 ; 70-80$ & Escudero and Ferragut, 2005 \\
\hline P. fragariae & T. urticae & 0.273 & 1.242 & 15.6 & 29.7 & $25 ; 88 \pm 7$ & Nascimento et al., 2008 \\
\hline C. caliornicus & T. turkestani & 0.267 & - & 17.89 & 42.93 & $25 ; 70-80$ & Escudero and Ferragut, 2005 \\
\hline C. californicus & T. urtiae & 0.209 & 1.23 & 17.55 & 22.92 & $25 ; 70-80$ & Canlas et al., 2006 \\
\hline P. macropilis & T. urticae & 0.193 & 1.213 & 18.45 & 35.34 & $26 ; 60 \pm 1$ & Da Silva et al., 2005 \\
\hline N. idaeus & T. urticae & 0.168 & - & 10.15 & 5.53 & $25 ; 77 \pm 2$ & Collier et al., 2007 \\
\hline P. fragariae & T. evansi & 0.123 & 1.131 & 17.4 & 8.5 & $25 ; 88 \pm 7$ & Nascimento et al., 2008 \\
\hline I. degenerans & T. urticae & 0.115 & - & 20.2 & 10.3 & $25 ; 75 \pm 5$ & Vantornhout, 2006 \\
\hline P. persimilis & T. evansi & 0.106 & - & 14.21 & 4.37 & $25 ; 70-80$ & Escudero and Ferragut, 2005 \\
\hline K. aberrans & T. urticae & 0.095 & - & 24.76 & 10.39 & $25 ; 65 \pm 1$ & Kasap, 2005 \\
\hline C. californicus & T. evansi & 0.084 & - & 14.5 & 3.33 & $25 ; 70-80$ & Escuderoand Ferragut, 2005 \\
\hline
\end{tabular}

${ }^{1}$ Biological parameters, $\mathrm{R}_{0}=$ net reproductive rate, $\mathrm{r}_{\mathrm{m}}$ = intrinsic rate of growth, $\mathrm{T}=$ mean generation time, and $\lambda$ = finite rate of growth. 
$P$. ersimilis had very low values of $r_{m}$ when fed eggs or the mixed diet due to, we assume, the experimental conditions, as the same predator fed with $T$. urticae at $25 \pm 1^{\circ} \mathrm{C}$ and $70-80 \% \mathrm{RH}$ with a photoperiod of 12:12 h L:D had an $r_{m}$ of 0.373 (Escudero and Ferragut, 2005).

Ragusa et al. (2000) also found a small generational time (T) for $C$. picanus fed with eggs of $T$. urticae (9 days). In turn, when this predator was fed with eggs of $P$. citri, its generational time increased to 15.9 days. Rioja and Vargas (2008) obtained $\mathrm{T}$ values of 12.46 and 13.91 days for $C$. picanus fed with a diet of mobile states and with a mixed diet of $O$. yothersi, respectively. From Table 4 , it is clear that a diet of $T$. cinnabarinus produces $T$ values coinciding with the values obtained for other phytoseiids in conditions of more favorable humidity, indicating that the experimental conditions did not extend the generational time as previously seen in other studies. From analyzing Table 5 , it is clear that the $\mathrm{T}$ values for $P$. persimilis are within the values obtained by other authors in experimental conditions of $70-80 \% \mathrm{RH}$. This parameter seems to be unaffected by low humidity.

According to Sabelis (1985), phytoseiid species whose $\lambda$ exceeds the numeric value of 1.2 are considered as promising candidates for biological control of prolific red spider mites. The values of this parameter obtained in this study are very close to the values obtained by Ragusa et al. (2000) for C. picanus fed with T. urticae eggs $(\lambda=1.458)$. On the other hand, Rioja and Vargas (2008) indicated that $C$. picanus fed with mobile stages and a mixed diet of $O$. yothersi had $\lambda$ values higher than 1.2 (1.29 and 1.27, respectively). If the results obtained for the intrinsic rate of growth in this study are added to these results, it may be proposed that $C$. picanus may be an efficient controller of red spider mites of the family Tetranychidae, thus behaving as a type II selective predator, such as $N$. californicus (Table 5).

The values of $\lambda$ obtained for $P$. persimilis with the two diets were lower than the values for the carmine spider mite. If the low values presented for the parameters $r_{m}$ and $R_{0}$ are added, it may be stated that the reproductive capacity of $P$. persimilis in conditions of low RH is very depressed, making this predator unable to control populations of the carmine spider mite in arid conditions, such as the conditions in northern Chile. The $\lambda$ value presented by $P$. persimilis in more favorable conditions surpasses the value of 1.2 (Escudero and Ferrugut, 2005). Those are the $\lambda$ values expected for specialist predators of this nature (Table 5 ).

C. picanus and P. persimilis complete their embryonic development and achieve reproduction when feeding preferably on eggs and juvenile states of T. cinnabarinus in laboratory conditions. The life table parameters shown by C. picanus are higher than the parameters exhibited by $P$. persimilis under the experimental conditions used (29.44 \pm $1.47^{\circ} \mathrm{C}, 42.35 \pm 5.01 \% \mathrm{RH}$ and a photoperiod of 14:10 h (L:D). P. persimilis had a high mortality due to the dehydration of its eggs at $42.35 \% \mathrm{RH}$. C. picanus could potentially control populations of $T$. cinnabarinus at the field level; this requires an evaluation of its predatory action in order to include it within an integrated management program for the carmine spider mite, in carnation or melon, in arid zones of Chile.

\section{Acknowledgments}

This work is part of the results of the doctoral thesis presented by the first author to the doctoral program in the Department Forest and Agriculture Sciences at the Faculty of Agronomy, Universidad de Chile. The authors are grateful for financial support received from the research project agreement between Comisión Nacional de Ciencia y Tecnología (CONICYT), Gobierno Regional de Tarapacá, Universidad Arturo Prat, Iquique, Chile and Universidad de Tarapacá, Arica, Chile. The first author thanks CRI-La Cruz and the Instituto de Investigaciones Agropecuarias (INIA) for the facilities granted to perform the laboratory tests. 


\title{
Resumen
}

\begin{abstract}
V. Tello, R. Vargas, J. Araya y A. Cardemil. 2009. Parámetros biológicos de Cydnodromus picanus Ragusa y Phytoseiulus persimilis (Athias-Henriot) (Acari: Phytoseiidae), sobre la arañita cinabarina, Tetranychus cinnabarinus (Boisduval) (Acari: Tetranychidae). Cien. Inv. Agr. 36(2):277-290. El desarrollo postembrionario, consumo y parámetros de tabla de vida de Cydnodromus (=Neoseiuslus) picanus Ragusa y Phytoseiulus persimilis (Athias-Henriot), fueron estudiados a $29,44 \pm 1,47^{\circ} \mathrm{C}, 42,35 \pm 5,01 \%$ de H.R. y un fotoperíodo de 14:10 h (L:O), para evaluar la potencialidad de estos depredadores sobre la arañita cinabarina Tetranychus cinnabarinus Boisduval. Los huevos, larvas y protoninfas de T. cinnabarinus pueden ser considerados alimentos óptimos para C. picanus obteniéndose una supervivencia de 100, 97 y $93 \%$, respectivamente. La supervivencia de $P$. persimilis fue de alrededor del $6,7 \%$ con los mismos alimentos, presentando una alta mortalidad a nivel de huevos por deshidratación. La duración del desarrollo postembrionario de $C$. picanus fue significativamente menor $(P<0,05)$ que el de $P$. persimilis al ser alimentados con huevos, larvas y deutoninfas de $T$. cinnabarinus. La tasa intrínseca de crecimiento $\left(r_{m}\right)$ fue sinificativamente mayor $(P<0,05)$ para $C$. picanus $(0,289 \mathrm{y}$ $0,307)$ que para $P$. persimilis $(0,019$ y 0,025$)$ alimentados con huevos y una mezcla de diferentes estados de T. cinnabarinus, respectivamente. Los valores de la tasa finita de crecimiento $(\lambda)$ también fueron significativamente $(P<0,05)$ mayores para $C$. picanus $(1,34$ y 1,36$)$ que para $P$. persimilis $(1,02$ y 1,03$)$ al alimentarlos con huevos y dieta mixta, respectivamente. Los valores altos de $r_{m}$ y $\lambda$ registrados para C. picanus en las condiciones experimentales son indicadores del posible control potencial que presentaría este fitoseido como depredador de T. cinnabarinus en condiciones de baja humedad relativa que son encontradas en las zonas áridas del desierto de Chile.
\end{abstract}

Palabras clave: Control biológico, depredación, desarrollo postembrionario, tabla de vida.

\section{References}

About-Setta, M.M., R.W. Dorrell, and C.C. Childres. 1986. Life 48: a BASIC computer program to calculate life table parameters for an insect or mites species. Flo. Ent. 69:690-697.

Ali, F.S. 1998. Life tables of Phytoseilus macropilis (Banks) (Gamasida: Phytseiidae) at different temperatures. Exp. Appl. Acarol. 22:335-342.

Ansaloni, T., S. Aucejo, and J.A. Jacas. 2007. Estimating the intrinsic rate of increase of Tetranychus urticae: which is the minimum number of immature individuals to consider? Exp. Appl. Acarol. 41:55-59.

Ashihara, W., T. Hamamura, and N. Shinkaji. 1978. Feeding, reproduction, and development of Phytoseiulus persimilis Athias-Henriot (Acarina:
Phytoseiidae) on various food substances. Bull. Fruit Tree Res. 2:91-98.

Bakker, F.M., M.E. Klein, N.C. Mesa, and A.R. Braun. 1993. Saturation deficit tolerante spectra of phytophagous mites and their phytoseiid predators on cassava. 1993. Exp. Appl. Acarol. 17(1-2):97-113.

Benuzzi, M. and L. Antoniacci. 1995. Recent updates about the biological and integrated control on strawberries. Rivista di Frutticoltura e di Ortofloricoltura (Italy) 57:63-65.

Birch, L.C. 1948. The intrinsic rate of natural increase of an insect population. J. Anim. Ecol., $17: 15-26$.

Çakmak, I., and M.A. Demiral. 2007. Response of Tetranychus cinnabarinus feeding on $\mathrm{NaCl}-$ stressed strawberry plants. Phytoparasitica $35: 37-49$. 
Çakmak, I., H. Başpinar, and N. Madanlar. 2005. Control of the carmine spider mite Tetranychus cinnabarinus Boisduval by the predatory mite Phytoseiulus persimilis (Athias - Henriot) in protected strawberries in Aydın. Turk. J. Agric. For. 29:250-265.

Canlas, L., H. Amano, N. Ochiai, and M. Takeda. 2006. Biology and predation of the Japanese strain of Neoseiulus californicus (McGregor) (Acari: Phytoseiidae). Systematic and Applied Acarology 11:141-157.

Chittenden, A.R., and Y. Saito. 2001. Why are there feeding and nonfeeding larvae in phytoseiid mites (Acari, Phytoseiidae)? J. Ethol. 19:55-62.

Collier, K., G. Albuquerque, J. De Lima, A. Pallini, and A. Molina-Rugama. 2007. Neoseiulus idaeus (Acari: Phytoseiidae) as a potential biocontrol agent of the two-spotted spider mite, Tetranychus urticae (Acari: Tetranychidae) in papaya: performance on different prey stage - host plant combinations. Exp Appl Acarol. 41:27-36.

Da Silva, F., G. Vasconcelos, M. Gondim, and J. Oliveira. 2005. Exigências térmicas e tabela de vida de fertilidade de Phytoseiulus macropilis (Banks) (Acari: Phytoseiidae). Neotropical Entomology 34:291-296.

De Courcy, W.M.E., L. Kravar-Garde, J.S. Fenton, and K.D. Sunderland. 2004. Phytoseiid mites in protected crops: the effect of humidity and food availability on eg hatch and adult life span of Iphiseius degenerans, Neoseiulus cucumeris, $N$. californicus and Phytoseiulus persimilis (Acari: Phytoseiidae). Exp. Appl. Acarol. 32:1-13.

De Vis, R.M.J., G.J. Moraes, and M.R. Bellini. 2006. Effect of air humidity on the egg viability of predatory mites (Acari: Phytoseiidae, Stigmaeidae) common on rubber trees in Brazil. Exp. Appl. Acarol. 38:25-32.

Escudero, L.A., and F. Ferragut. 2005. Life-history of predatory mites Neoseiulus californicus and Phytoseiulus persimilis (Acari: Phytoseiidae) on four spider mite species as prey, with special reference to Tetranychus evansi (Acari: Tetranychidae). Biological Control 32:378-384.

Ferrero, M., G.J. Moraes, S. Kreiter, M.-S. Tixier, and M. Knapp. 2007. Life tables of the predatory Phytoseiulus longipes feeding on Tetranychus evansi at four temperatures (Acari: Phytoseiidae, Tetranychidae). Exp. Appl. Acarol. 41:45-53.

Furuichi, H., S. Yano, A. Takafuji, and M. Osakabe. 2005. Prey preference of the predatory mite $\mathrm{NeO}$ - seiulus womersleyi Schicha is determined by spider mite webs. JEN 129:336-339.

Gotoh, T., A. Tsuchiya and Y. Kitashima. 2006. Influence of prey on developmental performance, reproduction and prey consumption of Neoseiulus californicus (Acari: Phytoseiidae). Exp Appl Acarol. 40:189-204.

Kasap, I. 2005. Life-history traits of the predaceous mite Kampimodromus aberrans (Oudemans) (Acarina: Phytoseiidae) on four different types of food. Biological Control 35: 40-45.

Kazak, C., And C. Kibritçi. 2008. Population Parameters of Tetranychus cinnabarinus Boisduval (Prostigmata: Tetranychidae) on Eight Strawberry Cultivars. Turk J Agric For. 32:19-27.

Kazak, C., S. Yildiz, and E. Sekeroglu. 2002. Biological characteristic and life tables of Neoseiulus umbricatus Chant (Acari: Phytoseiidae) at three constant temperatures. J. Pest Science, 75:118121.

Kim, Y.-H., and S.-G. Park. 2006. Optimum release times for biological control of the two-spotted spider mite Tetranychus urticae Koch (Acari: Tetranychidae) by Phytoseiulus persimilis Athias-Henriot (Acari: Phytoseidae) on the strawberry in greenhouses. Entomological Research 36:238-244.

Klein, C., and D.F. Waterhouse. 2000. The distribution and importance of arthropods associated with agriculture and forestry in Chile (Distribución e importancia de los artrópodos asociados a la agricultura y silvicultura en Chile). 234 p. ACIAR Monograph No. 68, Canberra, Australia.

La Rossa, R., and Y.N. Kahn. 2003. Dos programas de computadora para confeccionar tablas de vida de fertilidad y calcular parámetros biológicos y demográficos en áfidos (Homoptera: Aphidoidea). RIA (Argentina), 32:127-142.

Maia, A.H., A.J. Luiz, and C. Campanhola. 2000. Statistical inference on associated fertility life table parameters using jackknife technique: Computational aspects. J. Econ. Entomol. 93:511-518.

Mcmurtry, J.A., and B.A. Croft. 1997. Life styles of phytoseiid mites and their roles in biological control. Ann. Rev. Entomol. 42:291-321.

Moraes, G.J., J.A. Mcmurtry, H.A. Denmark, and C.B. Campos. 2004. A revised catalog of the mite family Phytoseiidae. Zootaxa 434:1-494.

Naher, L., and M. Haque. 2007. Biological Control of Tetranychus urticae (Acari: Tetranychidae) using Phytoseiullus persimilis (Acari: Phytoseiidae). Research Journal of Agriculture and Biological 
Sciences 3:550-553.

Nascimento, G., Moraes, G.J., I. Delalibera, and M. Knapp. 2008. Life history of the predatory mite Phytoseiulus fragariae on Tetranychus evansi and Tetranychus urticae (Acari: Phytoseiidae, Tetranychidae) at five temperatures. Exp. Appl. Acarol. 44:27-36.

Oku, K., S. Yano, and A. Takafuji. 2004. Nonlethal indirect effects of a native predatory mite, Amblyseius womersleyi Schicha (Acari: Phytoseiidae), on the phytophagous mite Tetranychus kanzawai Kishida (Acari: Tetranychidae). J. Ethol. 22:109-112.

Ragusa, S. 2000. A new Cydnodromus (Parasitiform, Phytoseiidae), from the Desert of the Northern Chile. Phytophaga 10:3-103.

Ragusa Di Chiara, S., R. Vargas, H. Tsolakis, and R. Ashbach. 2000. Laboratory studies on the influence of various food subtances on some biological and life-table parameters of Cydnodromus picanus Ragusa (Parasitiformes, Phytoseiidae) associated with citrus trees in the Chilean desert. Phytophaga 10:1-23.

Ragusa Di Chiara, S., and R. Vargas. 2002. On some phytoseiid mites (Parasitiformes, Phytoseiidae) from Chile. Phytophaga 12:129-139.

Rioja, T., and R. Vargas. 2008. Parámetros de tabla de vida y tasa de consumo de Cydnodromus picanus Ragusa, Amblyseius graminis Chant y Galendromus occidentalis (Nesbitt) (Acari: Phytoseiidae), sobre la arañita roja del palto Oligonychus yothersi (McGregor) (Acari: Tetranychidae). Agricultura Técnica. In press.

Sabelis, M.W. 1985. Development. p 43-53. In: W. Helle and M.W. Sabelis (eds) "Spider Mites, their biology, natural enemies and control". World Crop Pests. Vol 1B. Elsevier, Amsterdam. The Netherland.

Scopes, N.E.A. 1985. Biological control of spider mites. p 34-52. In: Hussey NW, Scopes NEA (eds) Biological Pest Control: The Glasshouse Experience, Blandford Press, Poole.

Strand, LL. 1994. Integrated Pest Management for Strawberries. University of California Division of Agriculture and Natural Resources publication 3351. University of California, Oakland, CA.

Swirski, E., S. Amitai, and N. Dorzia. 1970. Laboratorystudies of the feeding habits, post-embryonic survival, and oviposition of the predaceous mites Amblyseius chilenensis Dosse and Amblyseius hibisci Chant (Acarina: Phytoseiidae) on various kinds of food substances. Entomophaga 15: 93106.

Vantornhout, I. 2006. Biology and ecology of the predatory mite Iphiseius degenerans (Berlese) (Acari: Phytoseiidae). PhD thesis, Ghent University, Ghent, Belgium.

Vargas, R., N. Olivares, and A. Cardemil. 2005. Desarrollo postembrionario y parámetros de tabla de vida Typhlodromus pyri Scheuten, Cydnodromus californicus (Mc Gregor) (Acarina: Phytoseiidae) y Brevipalpus chilensis Baker (Acarina: Tenuipalpidae). Agricultura Técnica 65:147156.

Walzer, A., M. Castagnoli, S. Simoni, M. Liguori, E. Palevsky, and P. Schausberger. 2007. Intraspecific variation in humidity susceptibility of the predatory mite Neoseiulus californicus: Survival, development and reproduction. Biological Control. 41:42-52.

Zar, J.H. 2006. Biostatistical Analysis. Prentice-Hall Inc. Fifth ed., Englewood Cliffs, New Jersey, USA. 960 p.

Zundell, Ch., R. Hanna, U. Scheidegger, and P. Nagel. 2007. Living at the threshold: Where does the neotropical phytoseiid mite Typhlodromus aripo survive the dry season? Exp. Appl. Acarol. 41(1-2): 11-26. 
